We are grateful to Professor K. K. Mathen, All-India Institute of Hygiene and Public Health, Calcutta, for help in classifying the children into two groups and Mr H. B. N. Murthy for help in the estimation of serum proteins.

Our thanks are also due to the authorities of the Good Shepherd Orphanage for providing us every facility for carrying out the experiment described in this paper.

\title{
REFERENCES
}

Aykroyd, W. R., Patwardhan, V. N. \& Ranganathan, S. (1951). Hlth Bull., Simla, no. 23. Howe, P. E. (1921). F. biol. Chem. 49, rog.

Indian Council of Medical Research: Nutrition Advisory Committee (1948). Report of the Scientific Advisory Board for the Year 1948. New Delhi: Indian Council of Medical Research.

League of Nations Health Organization (1932). Quart. Bull. Hlth Org. L.o.N. I, 479.

Murthy, H. B. N., Swaminathan, M. \& Subrahmanyan, V. (1954). Brit. F. Nutr. 8, I I.

National Research Council: Food and Nutrition Board (1948). Repr. nat. Res. Coun., Wash., no. I29, p. I3.

Subrahmanyan, V., Murthy, H. B. N. \& Swaminathan, M. (1954). Brit. F. Nutr. 8, I.

\section{Protein Katabolism and Oxygen Consumption during Starvation in Infants, Young Adults and Old Men}

\author{
By R. A. McCANCE AND W. M. B. STRANGEWAYS \\ Medical Research Council Department of Experimental Medicine, University of \\ Cambridge
}

(Received I9 Fune 1953)

In their work on the partition of nitrogen in the urine of newborn breast-fed infants Barlow \& McCance (I948) found that the total nitrogen excreted during the first $48 \mathrm{~h}$ of life was of the order of $30 \mathrm{mg} / \mathrm{kg}$ body-weight $/ 24 \mathrm{~h}$. During this time the breast-fed infant obtains very little food and fluid and is in a state of physiological hydropenia and of almost complete starvation. Barlow \& McCance pointed out that Cathcart's (I907) and Benedict's (1915) work had shown that the starving adult, with an unrestricted water intake, excreted about $140 \mathrm{mg} \mathrm{N} / \mathrm{kg}$ body-weight $/ 24 \mathrm{~h}$. Although this was a large difference they did not claim that it represented a difference in the nitrogen katabolized because it was known from previous work (McCance \& Widdowson, 1947) that there was usually some retention of nitrogen over the first 2 days of life, and this had not been measured.

A re-examination of this evidence in 1949 suggested that the nitrogen katabolized by infants per $\mathrm{kg}$ body-weight in the first $48 \mathrm{~h}$ of life really was smaller than that katabolized by fasting adults. This was felt to be curious since Benedict $\&$ Talbot (19I5) had found that the calorie output of resting infants was $48 \mathrm{Cal} / \mathrm{kg} / 24 \mathrm{~h}$, whereas that of adults was only ${ }_{3} \mathrm{Cal} / \mathrm{kg} / 24 \mathrm{~h}$. Little help in the resolution of this difficulty could be obtained from the literature. Schlossmann \& Murschhauser (19r4) appeared to have been two of the few, if not the only, investigators to have measured the nitrogen katabolism and the calorie expenditure of the same starving baby. In 
a child about 6 months old they found the nitrogen katabolism to be $0.33 \mathrm{~g} / \mathrm{kg}$ during the second $24 \mathrm{~h}$ of starvation and the metabolic rate-probably not basal- $59 \cdot 5 \mathrm{Cal} . / \mathrm{kg}$. The nitrogen katabolism seemed very high, but the child's age and other circumstances made it unwise to compare the results with those obtained directly after birth.

The only other pertinent findings are those of Ashworth \& Cowgill (1938). Terroine and his collaborators (Terroine, Boy, Champagne $\&$ Mourot, I933) (see also Smuts, 1935; Brody, 1945) had established the fact that in a large series of animals, including man, the output of 'endogenous' nitrogen in the urine was about $2 \mathrm{mg}$ per basal Calorie consumed. Terroine $e t a l$. (1933), who had studied two growing pigs, believed that the relationship held for every age. The significance of the conception of 'endogenous' nitrogen has greatly changed (Beard, 1943) since it was introduced by Folin (1905), but if it be defined as the quantity of nitrogen excreted in the urine on a full calorie diet containing little or no protein, there can be no objection to the use of the term. Ashworth \& Cowgill (1938) found that this figure of $2 \mathrm{mg} \mathrm{N} / \mathrm{basal}$ Cal. held only for young adult rats, that in growing animals weighing $4 \circ \mathrm{g}$ the figure was about $\mathrm{I} \mathrm{mg}$ and that it rose to $2 \cdot 7$ in animals weighing $35^{\circ} \mathrm{g}$ or more. Brody (1945) did not accept these findings as having the significance attached to them by Ashworth \& Cowgill, and thought that the figure 2 could be taken to apply to all mammals by the time they had been weaned. Nevertheless, Ashworth \& Cowgill's work seemed to have been carefully done, and their results were at least suggestive in the light of the possibility that the starving newborn infant might have an unexpectedly small nitrogen breakdown. It was decided, therefore, to begin by studying the oxygen consumption, calorie output and nitrogen katabolism in each one of a series of newborn babies and to compare the results with those obtained from a series of normal young adults, maintained under essentially the same conditions. In order to achieve this it was planned to give the infants no food and only $50 \mathrm{ml}$. of water for the first $48 \mathrm{~h}$ of their lives and to allow the adults $350 \mathrm{ml}$. of water $/ 24 \mathrm{~h}$ but no food.

In some respects elderly men tend to stand up badly to undernutrition (McCance, 195I). In searching for an explanation it was considered that in starvation a greater proportion of their calorie output might be derived from the katabolism of protein than in young adults; that they were in fact in this respect the antithesis of the newborn infant. Here again, the literature provided no assistance and it was decided, therefore, to make the study of adults include a group of old men and to compare their katabolism of nitrogen with their calorie output under basal conditions, and both with the same measurements in infants and young adults. It was agreed to allow the old men $500 \mathrm{ml}$. water $/ 24 \mathrm{~h}$ during their period of starvation.

\section{EXPERIMENTAL}

\section{Subjects and methods}

Table I gives the age, height, weight, surface area, and certain other details about the subjects. The men all offered their services voluntarily after the nature and objects of the experiment had been explained to them. Permission to make these experiments was obtained from the parents of the infants and this was done before delivery to 
Table I. Description of subjects

\begin{tabular}{|c|c|c|c|c|c|}
\hline Subject & $\begin{array}{c}\text { Age } \\
\text { (years) }\end{array}$ & $\begin{array}{l}\text { Height } \\
(\mathrm{m})\end{array}$ & $\begin{array}{l}\text { Weight } \\
(\mathrm{kg})\end{array}$ & $\begin{array}{l}\text { Surface area } \\
\quad(\text { sq.m) }\end{array}$ & Remarks \\
\hline A & o & - & $3 \cdot 34$ & 0.230 & $\begin{array}{l}\text { First baby. Normal pregnancy } \\
\text { and delivery }\end{array}$ \\
\hline B & $\circ$ & - & $3 \cdot I I$ & 0.219 & $\begin{array}{l}\text { First baby. Normal pregnancy } \\
\text { and delivery }\end{array}$ \\
\hline $\mathrm{C}$ & o & - & $2 \cdot 70$ & 0.200 & $\begin{array}{l}\text { First baby. Normal pregnancy } \\
\text { and rapid delivery. Signs of } \\
\text { cerebral irritation on day } 2\end{array}$ \\
\hline $\mathrm{D}$ & ○ & - & 3.22 & 0.225 & $\begin{array}{l}\text { Second baby. Normal pregnancy } \\
\text { and delivery }\end{array}$ \\
\hline E & o & - & $4 \cdot 20$ & 0.268 & $\begin{array}{l}\text { Third baby. Normal pregnancy } \\
\text { and very easy delivery }\end{array}$ \\
\hline F & $\circ$ & - & $3.8 \mathrm{I}$ & $0.25 \mathrm{I}$ & $\begin{array}{l}\text { Fourth baby. Normal pregnancy } \\
\text { and delivery }\end{array}$ \\
\hline I & $2 \mathrm{I}$ & $I \cdot 74$ & $82 \cdot 3$ & $2 \cdot 02$ & \multirow{6}{*}{$\begin{array}{l}\text { These men were healthy sailors } \\
\text { who were taking part in other } \\
\text { experiments (Hervey \& } \\
\text { McCance, 1952) }\end{array}$} \\
\hline J & 26 & 1.69 & $68 \cdot 6$ & $I \cdot 8 I$ & \\
\hline $\mathrm{K}$ & 30 & $r \cdot 76$ & $72 \cdot 0$ & $\times 87$ & \\
\hline $\mathrm{L}$ & 22 & 1.66 & 66.1 & $\therefore 75$ & \\
\hline $\mathrm{M}$ & 21 & $1 \cdot 77$ & $69 \cdot 5$ & 1.87 & \\
\hline $\mathbf{N}$ & 21 & $x \cdot 65$ & $60 \cdot 7$ & $r \cdot 65$ & \\
\hline $\begin{array}{l}\mathrm{U} \\
\mathrm{V}\end{array}$ & $\begin{array}{l}74 \\
74\end{array}$ & $\begin{array}{r}r \cdot 54 \\
1 \cdot 62\end{array}$ & $\begin{array}{l}63 \cdot 8 \\
58 \cdot 6\end{array}$ & $\begin{array}{l}1 \cdot 62 \\
-62\end{array}$ & \multirow{5}{*}{$\begin{array}{l}\text { Healthy men from homes for the } \\
\text { aged }\end{array}$} \\
\hline W & 81 & 1.66 & 68.8 & $r \cdot 75$ & \\
\hline $\mathrm{x}$ & 84 & $1 \cdot 68$ & 85.6 & $r .94$ & \\
\hline $\mathrm{Y}^{*}$ & 79 & $1 \cdot 64$ & $69^{\circ} 0$ & $x \cdot 75$ & \\
\hline$Z^{*} \dagger$ & 77 & $1 \cdot 83$ & $56 \cdot 3$ & I.79 & \\
\hline
\end{tabular}

* On a low-protein diet before experiment.

+ Apprehensive; stopped after $48 \mathrm{~h}$.

enable the infants to be reared from birth in the respiration chamber. Only male infants were used. The fathers were allowed to visit their children during the tests, and the infants were taken from the chamber and shown to their mothers at least once in the $48 \mathrm{~h}$.

The young men were all sailors. During the experiment they lived in a small room with an almost constant, comfortably warm temperature. The old men were admitted to hospital and, like the young men, spent most of their time lying on their beds or moving quietly about the ward. Samples of blood were taken without anticoagulant before the period of starvation and at the end of each $24 \mathrm{~h}$ during the test. The serum was separated and used for the determination of urea. Urines were collected under toluene in periods of $24 \mathrm{~h}$ and the basal metabolic rate was determined by the Douglasbag technique (Best \& Taylor, 1950). Expired air was collected for 12 min periods from the young men and for $15 \mathrm{~min}$ periods from the old men. All were trained in the use of the mask and bag before the experiment began.

The metabolic rates of the infants were determined by means of an apparatus which operated upon the closed circuit principle and consisted of the following parts: (I) A cylindrical glass chamber, with a volume of about 601 ., closed by a quick release airtight door at the head end and mounted on stilts which gave it a downward tilt of $15^{\circ}$ from the head end to the foot end. Longitudinal runners inside it carried a Perspex frame for the baby. Below this lay a soft rubber bag which could be filled 
from a graduated column of water in a tube with a diameter of $10 \mathrm{~cm}$ situated outside the chamber and connected with the bag by rubber and metal tubing. A paper hygrometer and a mercury thermometer were mounted in the chamber. Through the foot end passed the copper inlet and outlet tubes for the gases, tubes for sampling the air in the chamber, for the admission of water to the bag and for the admission of oxygen to the apparatus, a glass tube for the manometer, glass tubes for stethoscopic purposes, and the wiring for the thermoelectric rectal thermometer. The manometer was designed to show small differences of pressure between the inside and the outside of the chamber. The gases leaving the chamber passed through copper piping with $\frac{1}{2}$ in. internal bore to (2) a Perspex box $8 \times 8 \times 12 \mathrm{~cm}$, which acted as a silencer and prevented alkali from being sucked back through the pump into the chamber. (3) A rotary air pump driven through a variable gear by an electric motor. (4) The absorbers for $\mathrm{CO}_{2}$ and water vapour. Two of these were mounted in parallel and only one was used at a time. The $\mathrm{CO}_{2}$ absorber consisted of a Perspex box. The gases passed through a duct down the side of the box and entered it through a perforated slot in the floor. When the pump was not running, alkali entered the slots and rose in the duct to the level inside the box. The dimensions of the box were $14 \times 7.5 \times 14 \mathrm{~cm}$, and it was fitted with three baffle plates fixed to the sides and a guard at the outlet tube in the ceiling to prevent alkali being carried out of the box by the stream of air. In the absorber box were placed $750 \mathrm{ml}$. of $\mathrm{CO}_{2}$-free $2 \mathrm{~N}-\mathrm{NaOH}$ solution and this could be sampled and analysed as and when required. To do so $12 \mathrm{ml}$. were withdrawn through a tube provided for this purpose in the side, the first few ml. were discarded, and $4.0 \mathrm{ml}$. used for each analysis (see below).

The water vapour was absorbed in a box $17 \times 7 \times 10 \mathrm{~cm}$, fitted with three baffle plates fixed to the ceiling and floor alternately and containing silica gel (Messrs Hopkin and Williams, Chadwell Heath, Essex) to which had been added cobalt chloride. This box was provided with a bypass tube made of rubber and fitted with a screw clip. By varying the amount of gas passing through the bypass the humidity of the gases returning to the chamber could be controlled. From this box the gases were led back to the chamber and distributed from perforated rubber tubing lying below the Perspex frame.

The chamber itself was mounted on the upper deck of a trolley and enclosed in a rectangular Perspex case $32 \times 22 \times 22$ in., the end of which could be removed very easily. The silencer trap, the motor and all the absorber sets were mounted on the lower deck. The apparatus was tested many times by burning alcohol in it and the chamber was always cleaned out with distilled water and sterilized with formalin vapour before a new subject was placed in it.

All the mothers were given gas-air analgesia during the delivery. The birth of the infant was watched and only infants whose birth was normal were used. A sample of cord blood was collected and the serum separated. As soon as the infant had emptied his bladder and respiration had been established, he was wrapped up, shown to his mother, and taken to the nursery. There he was washed, weighed and fitted with an apparatus for collecting any urine he might pass. He was then clothed in a napkin, frock, mittens, socks and a shawl and laid on his side on wide-meshed netting strung 
on the Perspex frame. He was secured on this frame by a nylon sheet passing round them both and on it he was lifted feet first into the chamber.

After all the fittings had been attached the door was firmly closed, but while this was being done a tap was left open to retain atmospheric pressure in the circuit. The motor was then started and allowed to run with the tap open till the temperature and humidity had settled to steady values. After these preliminaries, if the infant seemed quiet and likely to settle, about 21 . of oxygen were passed into the chamber and the last tap closed. The gases were then passed through fresh absorption boxes and after a further period of equilibration a sample of gas was taken from the chamber for analysis (Haldane), and $\mathrm{NaOH}$ for analysis was withdrawn from the $\mathrm{CO}_{2}$-absorption box. Throughout the test the humidity and temperature of the interior of the chamber were kept as constant as possible and varied in fact very little. As the oxygen in the circuit was used up and the $\mathrm{CO}_{2}$ absorbed, the pressure inside and outside the chamber was equalized by running water from the measuring column outside the chamber into the bag inside the chamber. (The flow could be reversed by changing the levels, and this was done between the tests when the circuit was being recharged with oxygen.) The metabolic rates were measured for $60-90 \mathrm{~min}$, and at the end of each test further samples of $\mathrm{NaOH}$ and of chamber gas were taken. Tests were made at suitable intervals night and day for the first $4^{8 \mathrm{~h}}$ of the infant's life, but the only measurements recorded in this paper were basal ones made while the infants were absolutely quiet and their temperatures within normal limits. Each figure given represents the mean of several tests. When measurements were not being made or contemplated in the next few hours the door of the chamber was usually opened and the motor switched off. When the baby passed meconium he was taken out, cleaned and fitted with a fresh napkin unless this interrupted one of the tests.

The urine was removed and stored under toluene soon after it had been passed. The last specimen was often voided when the baby was being handled at the end of the $48 \mathrm{~h}$; otherwise the apparatus was kept in place till the infant next emptied his bladder unless he had done so within the previous $2 \mathrm{~h}$. The collecting tube and bottle were cleaned out with distilled water and the washings analysed. Blood was collected from the heel at 24 and $4^{8} \mathrm{~h}$, the serum was separated and used for urea determination. The oxygen consumption was calculated from a curve obtained by taking readings at intervals of about $5 \mathrm{~min}$, assuming the initial volume of the chamber to be 581 . and deducting from this the volume of water run into the bag, the resulting volume being reduced to s.t.p. in the usual manner. The $\mathrm{CO}_{2}$ given out was determined by titrating the samples of $\mathrm{NaOH}$ withdrawn. Owing to the evaporation of water from the absorption box it was also necessary on each occasion to determine the change in normality of the total alkali. The sample of $\mathrm{NaOH}$ and $\mathrm{NaHCO}_{3}$ was therefore treated with $5 \mathrm{ml}$. $\mathrm{N}-\mathrm{BaCl}_{2}$ and titrated to the phenolphthalein end-point with $0.2 \mathrm{~N}-\mathrm{HCl}$ and the titration then continued to the end-point given by methyl red (Cumming \& Kay, I948). A correction was made for any rise or fall of $\mathrm{CO}_{2}$ in the circuit gases.

The percentage of oxygen in the chamber was maintained between 23 and 19 . The air in the circuit was usually kept $70 \%$ saturated with water vapour and it contained about $0.2 \% \mathrm{CO}_{2}$. The temperature of the chamber was usually held at $27^{\circ}$. The total 
nitrogen in the urine was determined by the micro-Kjeldahl technique and the urea in serum and urine by Lee \& Widdowson's (1937) method. A full description of this apparatus with diagrams and a much more detailed account of the procedure involved in measuring the infant's basal metabolic rates will be published later (Strangeways, 1954). Diagrams of the apparatus are available now and can be supplied if anyone wishes to construct one on similar lines.

The nitrogen katabolized by infants and adults was calculated from the increase or decrease in the quantity of urea nitrogen in the body water and the total nitrogen excreted in the urine. Seventy-two $\%$ of the fat-free parts of the body of the adults was assumed to consist of water; the amount of fat in the body was deduced from Fig. 3 given by McCance \& Widdowson (195I). Sixty-nine \% of the body-weight of these full-term normal babies was assumed to consist of water (Widdowson \& Spray, I95I).

\section{RESULTS}

Table 2 gives the basal metabolic rates and the nitrogen katabolism of the babies in the first 2 days of life and of the young sailors and of the old men for the 2 nd and 3 rd day of fasting. The figures for the adults on the Ist day of deprivation have not been

\section{Table 2. Basal metabolic rates and nitrogen catabolism of the subjects}

\begin{tabular}{|c|c|c|c|c|c|c|c|c|c|}
\hline \multirow[b]{2}{*}{ Subject } & \multicolumn{3}{|c|}{$\begin{array}{l}\text { Basal metabolic rate } \\
(\text { Cal. } / \mathrm{kg} / 24 \mathrm{~h})\end{array}$} & \multicolumn{3}{|c|}{$\begin{array}{l}\text { N katabolized } \\
(\mathrm{g} / \mathrm{kg} / 24 \mathrm{~h})\end{array}$} & \multicolumn{3}{|c|}{$\begin{array}{l}\text { Ratio, basal Cal./ } \\
\text { g N katabolized }\end{array}$} \\
\hline & Day I & Day 2 & Day 3 & Day I & Day 2 & Day 3 & Day I & Day 2 & Day 3 \\
\hline A & 45 & $6 I$ & - & 0.095 & 0.121 & - & 474 & 504 & - \\
\hline B & 47 & 48 & 一 & 0.063 & 0.105 & - & 747 & 457 & - \\
\hline $\mathrm{C}$ & 54 & 49 & - & 0.091 & 0.048 & 一 & 594 & 1020 & - \\
\hline $\mathrm{D}$ & 45 & 47 & - & 0.046 & 0.064 & - & 978 & 735 & - \\
\hline $\mathrm{E}$ & 5.2 & 53 & - & 0.051 & 0.046 & - & 1020 & I I 50 & 一 \\
\hline $\bar{F}$ & 47 & 48 & - & 0.074 & 0.088 & - & 635 & 541 & - \\
\hline I & $\ldots$ & 29 & 25 & - & 0.121 & 0.169 & - & 236 & $15^{\circ}$ \\
\hline $\mathrm{J}$ & 一 & 28 & 28 & - & 0.175 & 0.197 & - & $16 x$ & I 43 \\
\hline $\mathrm{K}$ & - & 26 & 24 & - & 0.137 & 0.199 & 一 & 192 & 120 \\
\hline L & - & 24 & 26 & - & 0.169 & 0.178 & - & 142 & 147 \\
\hline M & - & 29 & 25 & - & 0.145 & 0.217 & - & 199 & II 7 \\
\hline $\mathbf{N}$ & $\ldots$ & 27 & 25 & - & 0.195 & 0.182 & - & 138 & 136 \\
\hline $\mathrm{U}$ & 一 & 19 & 17 & - & 0.094 & 0.180 & - & 203 & 96 \\
\hline $\mathrm{V}$ & - & 22 & $2 I$ & - & $0 \cdot 108$ & 0.149 & - & 204 & 144 \\
\hline W & 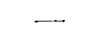 & $2 I$ & 20 & - & 0.088 & 0.190 & - & $23^{8}$ & 107 \\
\hline $\mathrm{X}$ & - & I 8 & I9 & - & O.IOI & 0.135 & - & 179 & 143 \\
\hline $\mathbf{Y}$ & - & 21 & 24 & - & $0 \cdot 100$ & 0.108 & - & 209 & 218 \\
\hline $\bar{Z}$ & - & 30 & - & - & 0.148 & - & 一 & 200 & - \\
\hline
\end{tabular}

given since they were variable and clearly belonged to the transition period between the normal state of full nutrition and hydration and the abnormal one of established starvation and hydropenia. Signs of an irregular transitional period were not evident just after birth, and since no observations were made on the 3 rd day of life the nitrogen catabolism and the basal metabolic rates of the infants have been given for the first and second $24 \mathrm{~h}$ of starvation. The respiratory quotients of the sailors (not given in the table) were around 0.77 on the 2 nd day and had fallen to about 0.74 by the $3^{\text {rd day. }}$ The figures for the old men were a little lower and averaged 0.72 on the 3 rd day. The 
respiratory quotients of the infants were $0 \cdot 85^{-0} \cdot 90$ soon after birth but by the end of the first $24 \mathrm{~h}$ of life had fallen to about 0.75 . These findings are similar to those of Benedict (1907) and of Benedict \& Talbot (1915) and indicate that, whatever the age of the subject, the carbohydrate stores available for combustion had largely been utilized by the beginning of the 2nd day of starvation.

The figures for the basal metabolic rates of the fasting sailors ranged from $24^{\circ} \circ$ to $28.8 \mathrm{Cal} . / \mathrm{kg} / 24 \mathrm{~h}$ on the 2 nd day and from 23.9 to 28.2 on the 3 rd day. These are in good agreement with the results obtained by others (Kleitman, 1926), and which might have been expected (Benedict, 1907, 1915; Lusk, 1928; Boothby \& Sandiford, 1929; Du Bois, 1936). Old $\operatorname{man} Z$ was always apprehensive and was not a good subject. His basal metabolic rate came to $29.7 \mathrm{Cal} / \mathrm{kg} / 24 \mathrm{~h}$ on the 2 nd day and he gave up the experiment at the end of it. The basal metabolic rates of the other five old men ranged from $\mathrm{I} 8 \cdot \mathrm{I}$ to $22 \cdot 0 \mathrm{Cal} . / \mathrm{kg} / 24 \mathrm{~h}$ on the 2 nd day and from 17.3 to $23 \cdot 6 \mathrm{Cal} . / \mathrm{kg} / 24 \mathrm{~h}$ on

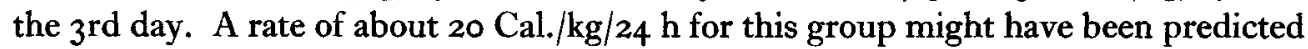
from a general knowledge of early starvation and from the tables given by Du Bois (1936), so here again the present results fall into line with those of others. The basal metabolic rates of the newborn infants varied from 45 to $54 \mathrm{Cal} / \mathrm{kg} / 24 \mathrm{~h}$ on the Ist day of their lives and from 47 to $6 \mathrm{r} \mathrm{Cal} / \mathrm{kg} / 24 \mathrm{~h}$ on the 2 nd day. Only one was over ${ }_{53} \mathrm{Cal} . \mathrm{kg} / 24 \mathrm{~h}$. The average figure given by Murlin, Conklin \& Marsh (1925) was $48 \mathrm{Cal} / \mathrm{kg} / 24 \mathrm{~h}$ ('Talbot, 1925). It may be concluded that there was nothing unusual about the basal metabolic rates of the present subjects.

The nitrogen katabolized by the sailors ranged from 0.121 to $0.195 \mathrm{~g} / \mathrm{kg} / 24 \mathrm{~h}$ on the 2nd day and from 0.169 to $0.217 \mathrm{~g} / \mathrm{kg} / 24 \mathrm{~h}$ on the 3 rd day. These figures are of the same order as those found by others for the nitrogen excreted in the urine on the and and $3^{\text {rd }}$ days of a fast, and since in all previous studies the water intake was not restricted in any way the nitrogen excreted may be taken as being equal to the nitrogen katabolized. Benedict ( 1907 ), for instance, found a range of $0.149-0.259 \mathrm{~g} / \mathrm{kg} / 24 \mathrm{~h}$ for the 2 nd day of a fast, Folin (quoted by Benedict) a figure of $0.130 \mathrm{~g} / \mathrm{kg} / 24 \mathrm{~h}$, Cathcart (1907) 0.219 and $0.209 \mathrm{~g} / \mathrm{kg} / 24 \mathrm{~h}$ on the 2 nd and 3 rd days respectively and Johannson, Landergren, Sonden \& Tigerstedt ( 1897 ) 0.190 and $0.200 \mathrm{~g} / \mathrm{kg} / 24 \mathrm{~h}$ for the same 2 days. Benedict \& Diefendorf ( 1907$)$ found $0.125 \mathrm{~g} / \mathrm{kg} / 24 \mathrm{~h}$ for a woman, and Brugsch \& Hirsch (1906) and Bönniger \& Mohr (1906) $0.140 \mathrm{~g} / \mathrm{kg} / 24 \mathrm{~h}$ also for a woman. The sailors had ratios of basal Cal./g N katabolized of from 138 to 236 on the 2 nd day and from II 7 to $15 \circ$ on the 3 rd day. The decrease, when of noteworthy size, was due mainly to a rise in the katabolism of nitrogen. Benedict's (19r5) tables show that Levanzin's ratios were 185 and 135 for 2 nd and 3 rd days of his fast, and it is evident that the sailors' ratios are representative of those to be expected in young adults.

The old men katabolized $0 \cdot 088-0 \cdot 148 \mathrm{~g} \mathrm{~N} / \mathrm{kg} / 24 \mathrm{~h}$ on the 2 nd day of their fasts and $0.108-0.190 \mathrm{~g} / \mathrm{kg} / 24 \mathrm{~h}$ on the 3 rd day. There are no previous figures with which to compare these, but it will be noted that they, like the basal metabolic rates, are somewhat lower than those of the sailors. The ratios of basal Cal./g N katabolized were, therefore, very like those of the sailors and ranged from 179 to 238 on the Ist and from 96 to 218 on the 2 nd day of the fast. 
The nitrogen katabolized by the baby boys ranged from 0.046 to $0.095 \mathrm{~g} / \mathrm{kg}$ during the first $24 \mathrm{~h}$ and from 0.046 to $0.12 \mathrm{I} / \mathrm{kg}$ during the second $24 \mathrm{~h}$. These are measurements that do not appear to have been made before, and they show that the amount of nitrogen broken down was on the whole considerably less than that broken down by the sailors and somewhat less than that by the old men; and this, taken in conjunction with the fact that the basal metabolic rates of the infants were at least twice as high as those of the adults, gave the infants much greater ratios of Cal./g N katabolized. These ranged from 457 to 1150 on the 2 nd day of their fast. It is perhaps a pity that the experiments on the newborn boys could not have been prolonged to the 3 rd day but it is open to argument whether they had not reached by the second $24 \mathrm{~h}$ a state of starvation and hydropenia similar in severity to that reached by the sailors and old men on the 3 rd day. At any rate they had lost a greater percentage of their original bodyweight. Perhaps, therefore, the and-day figures for the infants should be compared

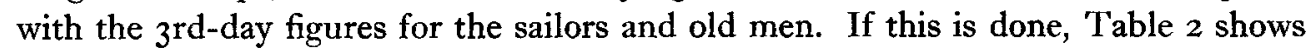
that the differences are considerably magnified.

Table 3 shows the average basal metabolic rates for the three different ages and the percentage of the calories derived from protein. The breakdown and combustion of protein contributed only $4 \%$ to the calories of the baby boys. Protein provided ${ }_{15}-20 \%$ of the sailors' basal calories and there was no change in this percentage with advancing years.

Table 3. Average values and standard deviations for basal calorie consumption and percentage of this derived from protein

\begin{tabular}{|c|c|c|c|c|c|c|}
\hline \multirow[b]{2}{*}{$\begin{array}{c}\text { Day of } \\
\text { starva- } \\
\text { tion }\end{array}$} & \multicolumn{2}{|c|}{ Baby boys } & \multicolumn{2}{|c|}{ Young men } & \multicolumn{2}{|c|}{ Old men } \\
\hline & $\begin{array}{c}\text { Basal } \\
\text { metabolic } \\
\text { rate } \\
\text { (Cal. } / \mathrm{kg} / \mathbf{2 4} \mathrm{h} \text { ) }\end{array}$ & $\begin{array}{l}\text { Cal. derived } \\
\text { from } \\
\text { protein } \\
(\%)\end{array}$ & $\begin{array}{c}\text { Basal } \\
\text { metabolic } \\
\text { rate } \\
(\mathrm{Cal} . / \mathrm{kg} / 24 \mathrm{~h})\end{array}$ & $\begin{array}{l}\text { Cal. derived } \\
\text { from } \\
\text { protein } \\
(\%)\end{array}$ & $\begin{array}{c}\text { Basal } \\
\text { metabolic } \\
\text { rate } \\
(\mathrm{Cal} . / \mathrm{kg} / \mathbf{2 4} \mathrm{h})\end{array}$ & $\begin{array}{c}\text { Cal. derived } \\
\text { from } \\
\text { protein } \\
(\%)\end{array}$ \\
\hline $\mathbf{I}$ & $48 \cdot 3 \pm 3 \cdot 4$ & $3.9 \pm 1 \cdot 0$ & - & - & - & - \\
\hline 2 & $5 I 0 \pm 4.9$ & $4 \cdot I \pm I 3$ & $27 \cdot 2 \pm 1 \cdot 7$ & $15.4 \pm$ & $2 \mathrm{I} \cdot 8 \pm 3 \cdot 8$ & $13.7 \pm 2.0$ \\
\hline 3 & - & 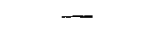 & $25^{6} \pm_{1} \cdot 4$ & $19.7 \pm 1.9$ & $20.4 \pm 2 \cdot I$ & $20 \cdot 3 \pm 5 \cdot 4$ \\
\hline
\end{tabular}

\section{DISCUSSION}

\section{The newborn infants}

The nitrogen breakdown of the newborn infants per kg body-weight was greater than the figures given by Barlow \& McCance (1948) for the nitrogen excretion. This difference was due to the nitrogen retention which so often takes place at that time of life, and which was measured in the present investigation. A paper is being prepared about it, and the difference requires no further discussion.

The numerical value of the ratio basal Cal./g $\mathrm{N}$ katabolized depends upon the soundness of two quite separate measurements. The ratios in this study might have been too high because the metabolic rates were not really basal, for any expenditure of energy on muscular exertion during starvation raises the calorie output but not the nitrogen breakdown (Voit, 1878 ; Lusk, 1928). The measurement of the true basal metabolic rate of a newborn infant has always been recognized as a troublesome task. 
Small spontaneous movements often introduce difficulties, particularly if the infants are hungry. Some workers have measured the calorie expenditure when the babies were apparently asleep, others after a little food or the administration of a barbiturate (Karlberg, 1952). The present investigators have done their best by keeping the infants under continuous observation over the whole of the first $48 \mathrm{~h}$ of their lives and by making their measurements of basal metabolic rate only when the infants really were, and had been, quiescent for some time. No drugs were given except a little phenobarbitone to one infant who showed slight signs of cerebral irritation. The results obtained are, as already stated, closely in line with those of others and the rates must be accepted as basal in the ordinary sense of the term. The ratio might also have been too high because only part of the urine formed was collected or because of some technical error in the Kjeldahl determination. The infants were not catheterized but each one was kept under observation till it passed urine spontaneously at the end of the 2nd day. There is no reason to think that any of the babies were returned to the nursery with urine in their bladders, and if they were the amount can only have been very small relative to that which they had already passed. Occasionally a few drops of urine were spilt while handling the baby. The total quantity probably never exceeded $\mathrm{r} \mathrm{ml}$. and an allowance was made for any such losses on the rare occasions when they did occur. Faults on the chemical side have been excluded by the usual blanks, controls and determinations of standard solutions. Urates, which often deposited in the cooled urines, were dissolved by warming before the urines were sampled. The ratios, therefore, must stand. They indicate that the babies were breaking down less than $2.0 \mathrm{mg}$ nitrogen/basal Cal. during starvation. How much lower the rate of breakdown would have been if the infants could have been given a high-calorie protein-free diet it is difficult to say, but it would almost certainly have been lower. The generalization of Terroine et al. (I933) and of Brody (1945) can scarcely hold for the human infant immediately after birth, and Ashworth \& Cowgill (1938) were probably right in thinking that the 'endogenous' nitrogen/basal Cal. ratio changed with age.

If we knew the mechanisms within the body that fix the Cal./N ratio in adults it would be easier to speculate on the reason why it is so much higher in newborn infants. The thyroid controls the basal metabolic rate of the body and may have something to do with fixing the ratio but the present evidence is rather against it, for thyroid activity appears to decrease in old age (Perlmutter \& Riggs, 1949), whereas the ratio has not been found to change. Less, but not much less, nitrogen is katabolized by infants per $\mathrm{kg}$ body-weight than by adults. The differences are somewhat reduced if the results are expressed per $\mathrm{kg}$ of cell mass. The growth hormone may be the agent that makes the ratio so high in infants or it may be insulin. The former has been said to act by inhibiting protein katabolism (Li \& Evans, 1947) but how it does so is another matter (Greenbaum, 1953). The nitrogen katabolized by adults ingesting no protein is greatly reduced by small amounts of carbohydrate (Hervey \& McCance, 1952). Insulin does stimulate the combustion of glucose and has been shown to be capable of acting remarkably like a growth hormone (Best, 1952). It would be interesting to know if the turnover rate of amino-acids was slower or faster in infants than in adults. Infants often have lower enzyme activities in their tissues than adults (Hines \& 
McCance, 1953). They may have less of the enzymes that destroy amino-acids (Epps, 1945). If the acids accumulate they may alter the turnover equilibrium between the cell proteins and the free acids in such a way that breakdown takes place more slowly. There is evidence (Crumpler, Dent \& Lindan, 1950) that there is more amino-nitrogen in the cord serum than there is in the maternal serum. The facility with which fat is made available for metabolism in the body of the newborn might explain why the breakdown of protein is so small. In other words, protein is not katabolized simply because plenty of fat and fatty acids present themselves at the required sites for breakdown and metabolism, and the enzymes are available for doing this. The latest work on the growth hormone (Greenbaum, 1953) suggests that it may be the responsible agent. From this point of view the infant at birth can be pictured as being in the position of an adult on a diet very low in protein but high in calories.

Further discussion must await the experimental results, but meanwhile there are some other points to which reference must be made. The first is that Karlberg (1952) was probably wrong in calculating his basal metabolic rates to assume that $15 \%$ of his infants' calories were derived from protein. The second is that the small percentage of the total calories that the starving human infant derives from protein just after birth must bear some relationship to the small percentage of the calories that can be derived from the protein in human milk if it is completely metabolized. It remains to be seen what the ratio basal Cal./g N katabolized will turn out to be in other newborn animalsfirstly in relation to the composition of their milk and secondly to their ratio basal Cal./g N katabolized at maturity. The third is that, were the ratio not so high, the loss of protein and consequently of weight in the first 2 days of life would certainly be greater than it is, more urea would be formed and would have to be excreted by kidneys which are incapable as it is of dealing with the relatively small amounts of urea which the tissues make.

\section{The old men}

It is evident that the ratio basal Cal./g $\mathrm{N}$ katabolized does not change appreciably with advancing years, and that whatever fixes it remains functionally effective into old age. This is true of many of the other bodily and cellular functions (Lansing, 195 I) and needs no further comment. A fall in the ratio, therefore, below the adult level may probably be dismissed as the reason why old men stand up badly to undernutrition. The matter has not yet been explored or the fact shown to hold for animals, and the reasons may be largely social and psychological. Information about protein metabolism during starvation must be germane in any investigation into protein requirements. The composition of human milk, low in protein as it is, provides more nitrogen/Cal. than is called for by the basal metabolism of the starving infant. The tendency among European and American adults is to eat a diet of which about $12 \%$ of the calories are derived from protein (Widdowson, 1936; Widdowson \& McCance, 1936). Albanese, Higgons, Vestal, Stephanson \& Malsch (r952) found a much lower proportion than this in a small group of old women, but the proportion has also been found to rise slightly in old age (Ohlson, Brewer, Cederquist, Jackson, Brown \& Roberts, 1948). However that may be, it certainly never approaches the $20 \%$ which the basal metabolism of an adult demands during starvation. 


\section{SUMMARY}

1. Normal newborn male infants and young and old men were allowed no food and a restricted fluid intake for $48-72 \mathrm{~h}$. Urine and blood were collected over this time and the basal metabolic rates were measured.

2. The basal metabolic rate of the three groups averaged 50,26 and $2 \mathrm{I} \mathrm{Cal.} / \mathrm{kg} / 24 \mathrm{~h}$ respectively during starvation.

3. The body nitrogen katabolized on these days averaged $0.075 \mathrm{~g} / \mathrm{kg} / 24 \mathrm{~h}$ in the infants, 0.17 in the young adults and 0.12 in the old men.

4. It follows that starving young adults and old people derived about $19 \%$ of their calories from protein but infants, during the first $48 \mathrm{~h}$ of their lives, only $4 \%$.

Miss Elizabeth Colbourn played a very important part in the investigations on the newborn infants, and the authors are very grateful to her. They are also indebted to Professor E. M. Glaser and Dr G. R. Hervey for their co-operation in the work on the sailors and to Dr E. M. Widdowson for consistently sound advice.

\section{REFERENCES}

Albanese, A. A., Higgons, R. A., Vestal, B., Stephanson, L. \& Malsch, M. (1952). Geriatrics, 7, rog.

Ashworth, U. S. \& Cowgill, G. R. (1938). F. Nutr. 15, 73.

Barlow, A. \& McCance, R. A. (1948). Arch. Dis. Childh. 23, 225.

Beard, H. H. (1943). Creatine and Creatinine Metabolism. London: Chapman and Hall.

Benedict, F. G. (1907). Publ. Carneg. Instn, no. 77.

Benedict, F. G. (I915). Publ. Carneg. Instn, no. 203.

Benedict, F. G. \& Diefendorf, A. R. (1907). Amer. F. Physiol. 18, 362.

Benedict, F. G. \& Talbot, F. B. (I9I 5). Publ. Carneg. Instn, no. 233.

Best, C. H. (1952). Diabetes, I, 257.

Best, C. H. \& Taylor, N. B. (1950). The Physiological Basis of Medical Practice. London: Baillière, Tindall and Cox.

Bönniger, M. \& Mohr, L. (Igo6). Z. exp. Path. Ther. 3, 675 .

Boothby, W. M. \& Sandiford, I. (1929). Amer. F. Physiol. 90, 290.

Brody, S. (1 945). Bioenergetics and Growth. New York: Reinhold Publishing Co.

Brugsch, T. \& Hirsch, R. (1906). Z. exp. Path. Ther. 3, 638.

Cathcart, E. P. (1907). Biochem. Z. 6, 109.

Crumpler, H. R., Dent, C. E. \& Lindan, O. (1950). Biochem. F. 47, 223.

Cumming, A. C. \& Kay, S. A. (1948). Quantitative Chemical Analysis. London: Gurney and Jackson. Du Bois, E. F. (1936). Basal Metabolism in Health and Disease. London: Baillière, Tindall and Cox. Epps, H. M. R. (1945). Biochem. F. 39, 37.

Folin, O. (1905). Amer. F. Physiol. 13, 66.

Greenbaum, A. L. (1953). Biochem. F. 54, 400.

Hervey, G. R. \& McCance, R. A. (1952). Proc. roy. Soc. B, 139, 527.

Hines, B. E. \& McCance, R. A. (1953). F. Physiol. 122, 188.

Johannson, J. E., Landergren, E., Sonden, K. \& Tigerstedt, R. (1897). Skand. Arch. Physiol. 7, 29.

Karlberg, P. (1952). Acta paediat., Stockh., 4r, Suppl. 89.

Kleitman, N. (1926). Amer. F. Physiol. 77, 233.

Lansing, A. I. (I951). Physiol. Rev. 31, 274.

Lee, M. H. \& Widdowson, E. M. (1937). Biochem. F. 31, 2035.

Li, C. H. \& Evans, H. M. (1947). Vitam. E Horm. 5, 197.

Lusk, G. (1928). The Elements of the Science of Nutrition, $4^{\text {th }}$ ed. Philadelphia and London: W. B. Saunders.

McCance, R. A. (195I). Spec. Rep. Ser. med. Res. Coun., Lond., no. 275.

McCance, R. A. \& Widdowson, E. M. (1947). Lancet, 252, 787.

McCance, R. A. \& Widdowson, E. M. (1951). Proc. roy. Soc. B, 138, 115.

Murlin, J. R., Conklin, R. E. \& Marsh, M. E. (1925). Amer, F. Dis. Child. 29, 1. 
Ohlson, M. A., Brewer, W. D., Cederquist, D. C., Jackson, L., Brown, E. G. \& Roberts, P. H. (1948). 7. Amer, diet. Ass. 24, 744.

Perlmutter, M. \& Riggs, D. S. (1949). F. clin. Endocr. 9, $43^{\circ}$.

Schlossmann, A. \& Murschhauser, H. (I914). Biochem. Z. 58, 483 .

Smuts, D. B. (1935). F. Nutr. 9, 403.

Strangeways, W. M. B. (1954). To be published.

Talbot, F. B. (1925). Physiol. Rev. 5, 477.

Terroine, E. F., Boy, G., Champagne, N. \& Mourot, G. (1933). Bull. Soc. Chim. biol., Paris, I5, 42.

Voit, C. (1878). Z. Biol. 14, sect. 12, 57 .

Widdowson, E. M. (ฯ.936). F. Hyg., Camb., 36, 269.

Widdowson, E. M. \& McCance, R. A. (1936). F. Hyg., Camb., 36, 293.

Widdowson, E. M. \& Spray, C. M. (1951). Arch. Dis. Childh. 26, 205.

\title{
Studies of the Site of Conversion of $\beta$-Carotene Injected Intravenously into Rats
}

\author{
BY J. G. BIERI AND CLIFFORD J. POLLARD \\ Department of Biochemistry and Nutrition, University of Texas Medical Branch, \\ Galveston, Texas
}

(Received 26 fune 1953)

It has been known since the work of Drummond, Gilding \& Macwalter (I934) and Drummond \& Macwalter (r935) that when colloidal carotene is introduced directly into the circulation of animals the liver rapidly removes the pigment much as it does many other colloidal substances. Such carotene, as well as that deposited in the liver when colloidal carotene is given by other parenteral routes, is essentially not available to the animal as a source of vitamin $A$ and may still be found in the liver after the animal has died from an apparent deficiency of the vitamin (Lease, Lease, Steenbock \& Baumann, 1942; Sexton, Mehl \& Deuel, 1946). With the discovery by Tomarelli, Charney \& Bernhart (1946) that parenteral carotene can serve as an effective source of vitamin A provided it is solubilized in water with a surface-active agent, it became apparent that the parenteral utilization of the provitamin was primarily a question of its physical state in the aqueous medium administered.

Recently, Eaton, Matterson, Decker, Helmboldt \& Jungherr (r95I) injected an aqueous suspension of carotene intravenously into vitamin A-depleted calves and observed slight increases in plasma vitamin A levels. No increased storage of vitamin $A$ in the liver, however, was found. Kowalewski, Henrotin \& van Geertruyden (I95 I) have reported that colloidal carotene injected intravenously into dogs gave rise to considerable increases in vitamin $\mathrm{A}$ in the serum and liver within $2 \mathrm{~h}$.

In a previous study of the availability of solubilized carotene injected intramuscularly into vitamin A-depleted rats (Bieri \& Schultze, I95 I $b$ ), only small amounts of vitamin A were found in the serum and kidneys, and none was present in the liver. This indicated a rather inefficient utilization of the parenteral carotene, and subsequent investigation 